\title{
Possible solutions for the reduction of carbon emissions during operation of lignite power unit
}

\author{
Totyo Totev ${ }^{l}$, and Borislav Ignatov ${ }^{2}$ \\ ${ }^{1}$ Technical University of Sofia, FPEPM, Bulgaria \\ ${ }^{2}$ Technical University of Sofia, FPEPM, Bulgaria
}

\begin{abstract}
In order to continue their operation, the power plants of the Maritsa East Complex have to meet the contemporary environmental requirements, which are becoming more and more stringent. Along with them, there is an increase in the cost of carbon allowances that every fossil fuel power plant needs to buy in order to continue its operation. This increases the cost of electricity produced by them. One way to reduce carbon dioxide emissions $\mathrm{CO}_{2}$ generated by power plants burning Bulgarian lignite is to implement a more efficient power generation cycle.
\end{abstract}

\section{Introduction}

Each country must rely on its own energy sources. In this way, it gains independence for its energy system, which in turn leads to increased competitiveness of its economy. The only nationally significant energy source owned by the Bulgarian country is the lignite coal extracted in the Maritsa East Complex.

In order to continue their operation, the power plants of the Maritsa East Complex have to meet the contemporary environmental requirements, which are becoming more and more stringent. Along with them, there is an increase in the cost of carbon allowances that every fossil fuel power plant needs to buy in order to continue its operation. This increases the cost of electricity produced by them. One way to reduce carbon dioxide emissions $\mathrm{CO}_{2}$ generated by power plants burning Bulgarian lignite is to implement a more efficient power generation cycle. There are a number of solutions for increasing the efficiency of a power unit burning lignite coal. This article examines the case where a gas turbine is added to the power units currently present in the Maritsa East Complex.

The gas turbine and the conventional power unit (PU) that operates using lignite coal from the Maritsa East complex will work together, and the flue gas from the GT will be fed to the furnace chamber of the power boiler to utilize its heat. The following questions are addressed in the article:

1. Choice of power for the GT, which must reflect the following limitations:

- The existing power unit must be able to operate independently, i.e. its work must not depend on the work of the GT;

- The operating range of the lignite-burning power unit must be kept as it stands (145 to $225 \mathrm{MW}$ );

- No significant changes to the existing facilities in the power unit must be made. 
2. The assessment of the change in the technical parameters of operation of the GT and the lignite-coal PU is done by simulating the processes in a digital software environment;

3. An environmental assessment of the joint work of the GT and the conventional PU was carried out. Emphasis is placed on the emissions of sulfur dioxide $\left(\mathrm{SO}_{2}\right)$ and carbon dioxide ( 2 ) emitted into the atmosphere during their operation.

\section{Choosing the power of the gas turbine}

Article [1] assessed the techno-economic and ecological parameters of a power unit burning Bulgarian lignite coal. The power unit simulated in the GateCycle software environment has the most widely used power boiler, namely P-62. It works in a monoblock with a steam turbine. To increase the existing power unit's efficiency, we add a gas turbine with a generator, and the flue gases that leave it are fed to the existing power boiler (Fig. 1). The gas turbine is designed to burn natural gas, as this fuel emits the least carbon emissions from all fossil fuels.

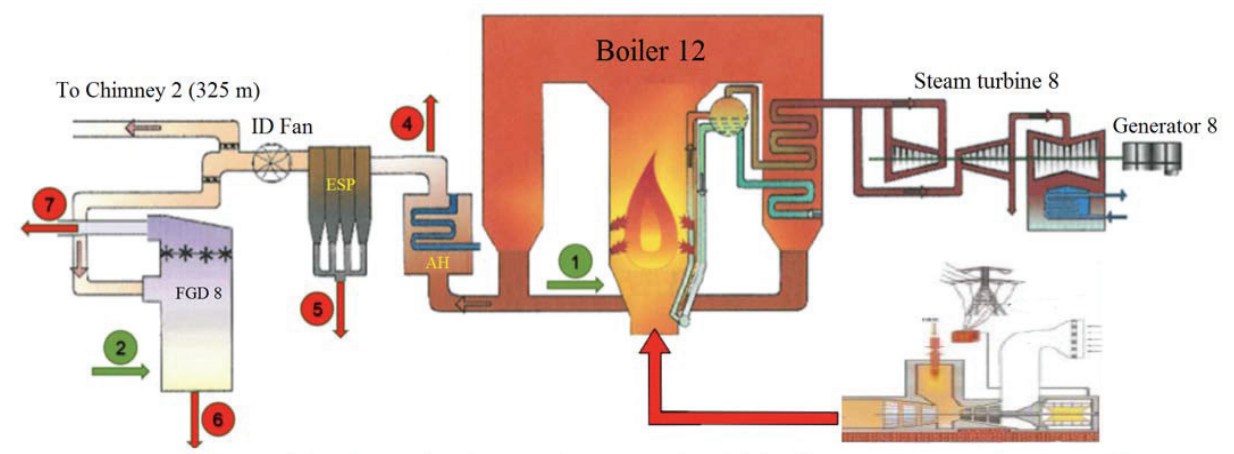

Fig. 1. General view of the thermal scheme of power unit with boiler type P-62 and a gas turbine

The choice of nominal power of the gas turbine takes into account the following restrictions: the existing power unit must be able to operate independently, i.e. its work must not rely on the operation of the gas turbine; the operating range of the power unit burning lignite coal must be preserved in its current form (from 145 to $225 \mathrm{MW}$ ); no significant changes to the existing facilities in the power unit must be made.

A number of options were played out in the GateCycle software environment in order to select a value for the power of the gas turbine that satisfies the outlined requirements. With the proposed scheme of adding a gas turbine to the existing power unit, the flue gases after the gas turbine, which have a high temperature - above $585{ }^{\circ} \mathrm{C}$, are fed to the furnace chamber of the power boiler. The boiler acts as a boiler-utilizer that absorbs the heat carried by the flue gases after the gas turbine. This leads to several positive effects, namely: reduced fuel consumption of lignite coal (while maintaining electrical power); decrease in the concentration of sulfur dioxide in the flue gases; decrease in the concentration of carbon dioxide in the flue gases; decrease in the concentration of other pollutants in the flue gases, such as dust, heavy metals, mercury and others; decrease in the amount of organized air supplied for combustion to the combustion systems of the power boiler; reduction in the power unit's own needs, etc.

The described scheme was modelled in the software environment GateCycle as illustrated in Fig. 2. 


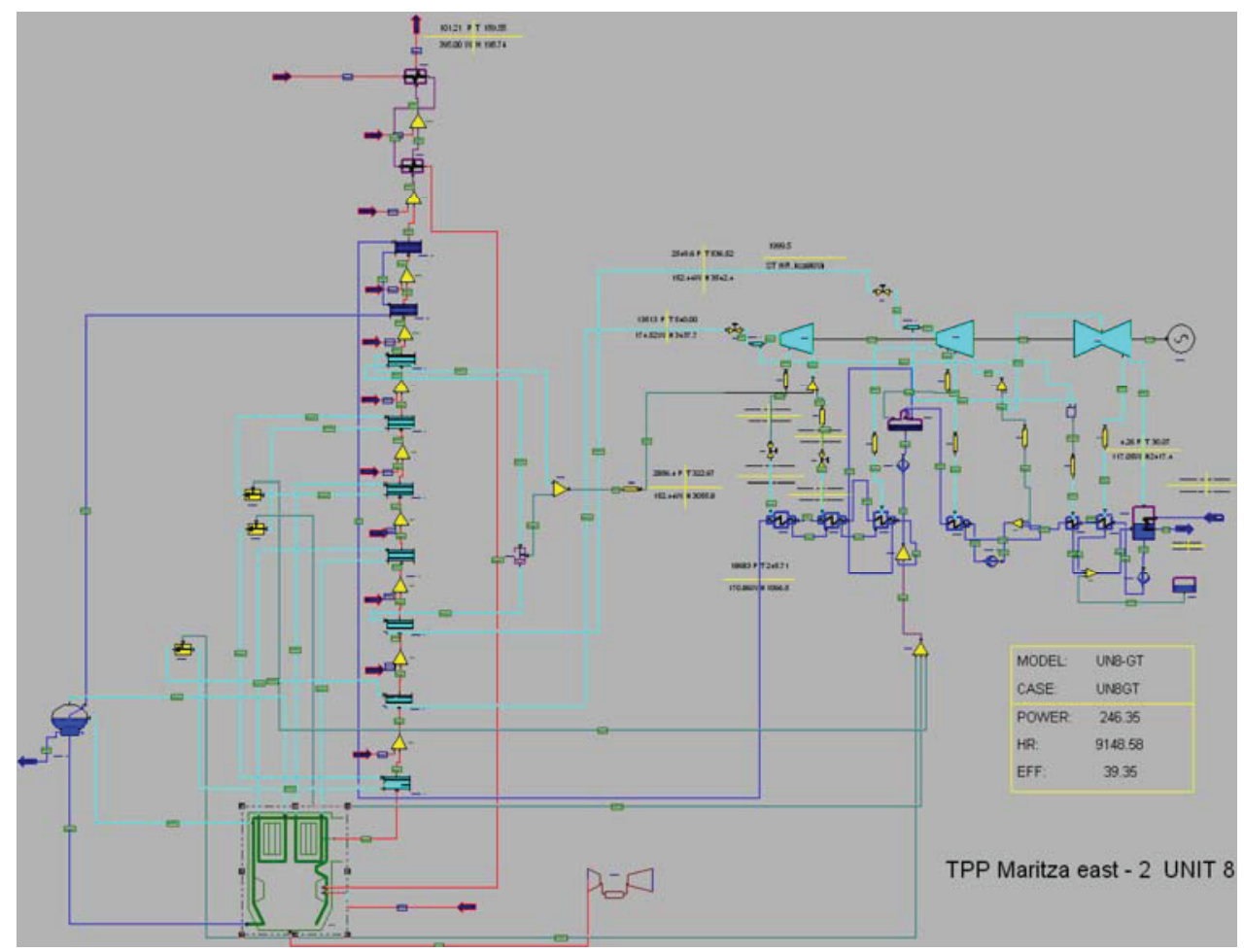

Fig. 2. Model of a steam-gas cycle of a power unit burning lignite coal with added gas turbine in the software environment GateCycle.

Model experiments were performed with 3 types of gas turbines, varying in power: 20 MW; 37.5 MW; 75 MW.

The flue gases after the gas turbine which are fed to the furnace chamber of the boiler contain about $16 \%$ oxygen. This reduces the amount of organized air supplied to the boiler. Therefore, the external air heater (EAH) is in danger of being left without sufficient airflow to cool it. This can lead to its destruction. Therefore, when choosing the power of the gas turbine, one of the main requirements is to have a sufficient volume of organized air to cool down the flue gases in the EAH. If this condition is not met and a larger gas turbine is installed, this will require a reconstruction in the tail section of the boiler, connected to the EAH.

Fig. 3 presents graphically some of the results obtained from the simulation studies. It visualizes the change in the flow of organized air supplied for combustion to the combustion systems of the boiler after the EAH as a function of the electricity produced by the power unit (steam turbine + gas turbine) at different powers of the gas turbine connected to it (20 MW; 37.5 MW; $75 \mathrm{MW}$ ).

Fig. 4 shows the change in the temperature of the flue gases after the EAH as a function of the electricity produced by the unit.

From the presented results it is evident that the choice of power of $37.5 \mathrm{MW}$ of the gasturbine unit is the most suitable for the set purposes, because the operating range of the power unit is from 180 to $262 \mathrm{MW}$. If we consider the electric power obtained only from the steam turbine, it is from 143 to $225 \mathrm{MW}$. In addition, there is a sufficient flow of organized air to pass through the $\mathrm{AH}$, and the temperature of the flue gases after the $\mathrm{AH}$ varies in the range from $197.96{ }^{\circ} \mathrm{C}$ at minimum load, to $189.21{ }^{\circ} \mathrm{C}$ at maximum load. 


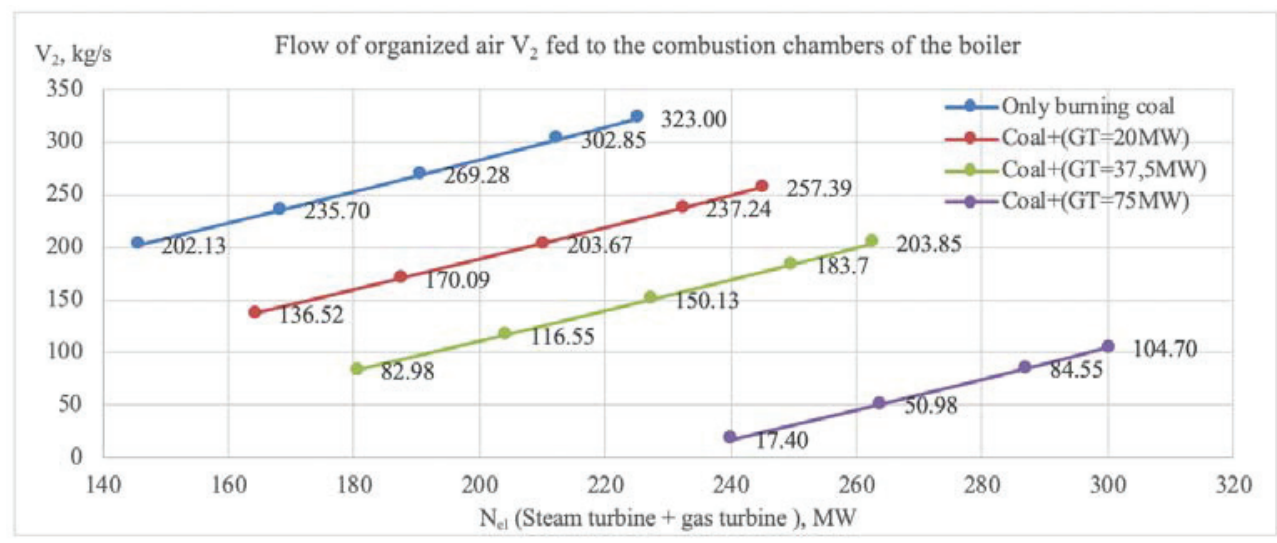

Fig. 3. Change in the flow of organized air fed for combustion to the combustion systems of the boiler as a function of the power of the gas turbine at different levels of produced electric power

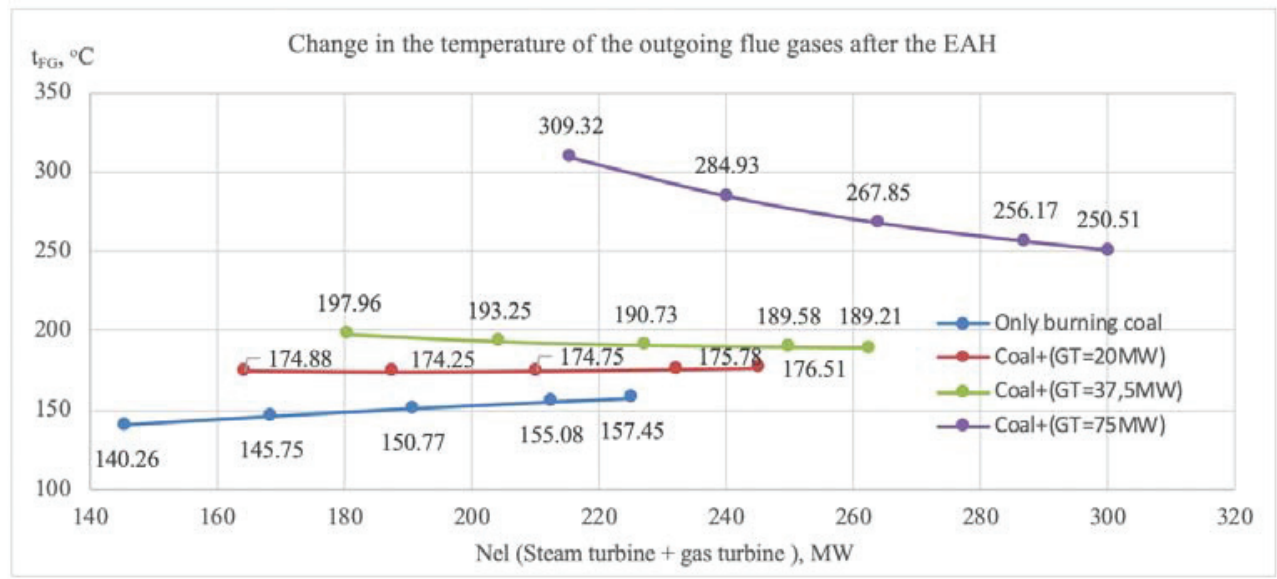

Fig. 4. Change in the temperature of the outgoing flue gases after the EAH as a function of the power of the gas turbine at different levels of produced electric power

\section{Assessment of technical parameters of the steam-gas cycle of a power unit burning lignite coal which also has a gas turbine}

The technical parameters assessment of the operation of the steam-gas cycle of a power unit burning lignite coal which also has a gas turbine is performed in the GateCycle software environment. Three thermal schemes with minimal differences are simulated: Scheme 1 operation of the power unit only on lignite coal; Scheme 2 - joint operation of the existing power unit (burning lignite coal) with added gas turbine with a capacity of $37.5 \mathrm{MW}$; Scheme 3 - joint operation of the existing power unit with an added gas turbine with a capacity of 37.5 MW and stopped high pressure heaters HPH 6 and HPH 7.

The obtained results are summarized in tabular form in Table 1. It shows data for each of the schemes for minimum, average and maximum load of the unit.

From the results presented so far we can draw the following conclusions:

- The more we reduce the supply of steam to the regenerative system, the lower the temperature of the flue gases after the air heater. In the case when we exclude HPH 
6 and $\mathrm{HPH} 7, \mathrm{t}_{\mathrm{FG}}$ assumes values ranging from $181.4{ }^{\circ} \mathrm{C}$ at minimum load, to 174.3 ${ }^{\circ} \mathrm{C}$ at maximum load. These temperatures are closest to the values we have when the power unit burns only lignite coal;

- The change of the temperature of the supply water shows that the lower the value is at the entrance of the boiler, the lower the temperature of the flue gases after the $\mathrm{AH}$, which leads to a reduction in the losses of exhaust gases generated by the energy boiler;

- The efficiency values of the power unit show that when we add a gas turbine to the lignite power unit, the efficiency of the unit increases. This is explained by the higher efficiency of the gas turbine module on the one hand, and the subsequent utilization of the flue gases leaving the gas turbine with high temperature and their supply to the energy boiler on the other hand. The average increase in the efficiency of the power unit is about $3.5 \%$

Table 1 - Results from the model studies of the steam-gas cycle of a power unit burning lignite coal with a gas turbine at 3 heat schemes. For each of the schemes, the acquired results for minimal, average and maximum load are presented

\begin{tabular}{|c|c|c|c|c|c|c|c|c|c|c|c|}
\hline \multirow{3}{*}{$\begin{array}{l}\text { No } \\
1\end{array}$} & \multirow{3}{*}{$\begin{array}{l}\text { Parameter } \\
\text { Fuel consumption - lignite coal }\end{array}$} & \multirow{3}{*}{$\begin{array}{c}\text { Dim. } \\
\mathrm{t} / \mathrm{h}\end{array}$} & \multirow{2}{*}{\multicolumn{3}{|c|}{$\begin{array}{c}\begin{array}{c}\text { Burning only lignite } \\
\text { coal }\end{array} \\
\text { Scheme } 1\end{array}$}} & \multirow{2}{*}{\multicolumn{3}{|c|}{$\begin{array}{c}\begin{array}{c}\text { Coal }+ \text { Gas } \\
\text { Turbine }=37.5 \mathrm{MW}\end{array} \\
\text { Scheme } 2\end{array}$}} & \multirow{2}{*}{\multicolumn{3}{|c|}{$\begin{array}{c}\text { Coal + Gas Turbine }= \\
37.5 \text { MW (without } \\
\text { HPH } 7 \text { and HPH 6) } \\
\text { Scheme } 3\end{array}$}} \\
\hline & & & & & & & & & & & \\
\hline & & & 216.7 & 288.7 & 346.3 & 180.7 & 252.7 & 310.3 & 180.7 & 252.7 & 310.3 \\
\hline 2 & Fuel consumption - natural gas & $\mathrm{t} / \mathrm{h}$ & 0.0 & 0.0 & 0.0 & 7.2 & 7.2 & 7.2 & 7.2 & 7.2 & 7.2 \\
\hline 3 & $\begin{array}{l}\text { Electric power produced by the } \\
\text { steam turbine for } 1 \text { hour }\end{array}$ & MWh & 145.7 & 190.8 & 225.3 & 143.0 & 186.8 & 225.2 & 143.2 & 189.9 & 225.3 \\
\hline 4 & $\begin{array}{l}\text { Electric power produced by the gas } \\
\text { turbine for } 1 \text { hour }\end{array}$ & MWh & 0.0 & 0.0 & 0.0 & 37.5 & 37.5 & 37.5 & 37.5 & 37.5 & 37.5 \\
\hline 5 & $\begin{array}{l}\text { Electric power produced by the } \\
\text { electric unit for } 1 \text { hour }\end{array}$ & MWh & 145.7 & 190.8 & 225.3 & 180.5 & 224.3 & 262.7 & 180.7 & 227.4 & 262.8 \\
\hline 6 & Efficiency of the power unit & $\%$ & 37.5 & 36.8 & 36.3 & 41.6 & 40.2 & 39.2 & 41.7 & 40.3 & 39.2 \\
\hline 7 & Efficiency of the power boiler & $\%$ & 85.1 & 85.4 & 85.7 & 82.4 & 83.3 & 83.5 & 84.0 & 84.8 & 84.9 \\
\hline 8 & $\begin{array}{l}\text { Temperature of the flue gases after } \\
\text { the EAH }\end{array}$ & $\mathrm{C}$ & 140.3 & 150.8 & 157.5 & 198.0 & 190.7 & 189.2 & 181.4 & 174.9 & 174.3 \\
\hline 9 & Flow of air after the EAH & $\mathrm{kg} / \mathrm{s}$ & 291.9 & 375.6 & 442.5 & 269.5 & 353.2 & 420.1 & 269.5 & 353.2 & 420.1 \\
\hline 10 & $\begin{array}{l}\text { Temperature of the organized air } \\
\text { after the EAH }\end{array}$ & $\mathrm{C}$ & 231.6 & 241.9 & 249.2 & 266.2 & 278.7 & 283.0 & 243.2 & 254.4 & 259.7 \\
\hline 11 & $\begin{array}{l}\text { Flow of the organized air after the } \\
\text { EAH }\end{array}$ & $\mathrm{kg} / \mathrm{s}$ & 202.1 & 269.3 & 323.0 & 83.0 & 150.1 & 203.9 & 83.0 & 150.1 & 203.9 \\
\hline 12 & $\begin{array}{l}\text { Temperature of the supply water - } \\
\text { at the entrance of the economizer }\end{array}$ & $\mathrm{C}$ & 228.3 & 241.3 & 249.2 & 226.8 & 240.3 & 248.6 & 191.2 & 198.6 & 202.9 \\
\hline 13 & $\begin{array}{l}\text { Flow of the supply water - at the } \\
\text { entrance of the economizer }\end{array}$ & $\mathrm{kg} / \mathrm{s}$ & 118.6 & 155.7 & 185.5 & 115.1 & 152.3 & 182.1 & 109.6 & 143.0 & 169.4 \\
\hline 14 & $\begin{array}{l}\text { Temperature of the fresh steam - at } \\
\text { the entrance of the high-pressure } \\
\text { cylinder }\end{array}$ & $\mathrm{C}$ & 539.5 & 544.7 & 547.6 & 537.5 & 543.2 & 546.4 & 538.5 & 545.9 & 549.6 \\
\hline 15 & $\begin{array}{l}\text { Flow of the fresh steam - at the } \\
\text { entrance of the high-pressure } \\
\text { cylinder }\end{array}$ & $\mathrm{kg} / \mathrm{s}$ & 119.4 & 158.4 & 189.4 & 115.4 & 155.0 & 186.2 & 111.6 & 147.6 & 175.5 \\
\hline 16 & $\begin{array}{l}\text { Steam temperature - at the entrance } \\
\text { of the condenser }\end{array}$ & $\mathrm{C}$ & 26.7 & 29.1 & 31.0 & 26.4 & 28.9 & 30.8 & 26.8 & 29.4 & 31.4 \\
\hline 17 & $\begin{array}{l}\text { Steam flow - at the entrance of the } \\
\text { condenser }\end{array}$ & $\mathrm{kg} / \mathrm{s}$ & 82.8 & 107.1 & 126.1 & 80.2 & 105.0 & 124.2 & 82.9 & 108.9 & 129.2 \\
\hline 18 & Pressure in the condenser & $\mathrm{kPa}$ & 3.5 & 4.0 & 4.5 & 3.4 & 4.0 & 4.4 & 3.5 & 4.1 & 4.6 \\
\hline
\end{tabular}

\section{Ecological assessment of the combustion in a steam-gas cycle energy unit}

When implementing a scheme in which we add a gas turbine with $\mathrm{N}_{\mathrm{el}}=37.5 \mathrm{MW}$ to an existing lignite power unit, along with increasing the installed capacity and increasing the 
efficiency of the unit, there is a reduction in the emissions of pollutants and greenhouse gases. The largest reduction is observed in the emissions of the following gases:

- carbon dioxide $\mathrm{CO}_{2}$ - it is a greenhouse gas and the reduction of its emissions is due to the following reasons: the amount of burned lignite coal is reduced on average by 36 $\mathrm{t} / \mathrm{h}$ (in order to produce the same amount of electricity); lower emissions due to the burning of natural gas; increase in the efficiency of the proposed scheme.

- sulphur dioxide $\mathrm{SO}_{2}$ - the reduction of emissions is due to the reduction of the consumption of burned lignite coal (for the same amount of produced electricity).

Using the data presented in Table 1, the mass flows of carbon dioxide $\mathrm{CO}_{2}$ and sulfur dioxide $\mathrm{SO}_{2}$ generated by the power unit have been calculated in the considered 3 cases. The results are presented in Table 2.

From article [1] we know that during the operation of a lignite coal power unit, its specific consumption of carbon dioxide $\mathbf{m C O}_{\mathbf{C O}}$ is $1.1203 \mathrm{t}_{\mathrm{CO} 2} / \mathrm{MWh}$. When modeling the operation of the gas turbine with a capacity of $37.5 \mathrm{MW}$, we used pure methane $\mathrm{CH}_{4}$ as fuel. The specific carbon dioxide consumption of the gas turbine is $0.528 \mathrm{t}_{\mathrm{CO} 2} / \mathrm{MWh}$. Therefore, when we replace some of the lignite coal burned with pure methane, the total amount of carbon dioxide emissions generated by the combined power unit decreases. This can be seen from the results presented in Table 2 and from Fig. 10. It also shows that with a decrease in the electricity produced by the power unit, the specific consumption of $\mathrm{CO}_{2}$ decreases. This is because the change in the load of the unit is only at the expense of reducing the consumption of lignite coal, while the gas turbine operates at constant power. The reduction of carbon dioxide emissions ranges from $7.54 \%$ at maximum load to $10.98 \%$ at minimum load.

Table 2 - Determining the mass and the specific consumption of carbon dioxide and sulphur dioxide in different operating modes

\begin{tabular}{|c|c|c|c|c|c|c|c|}
\hline Parameter & $\mathrm{N}_{t}$ & $\mathrm{~B}_{-\ldots}$ & $\mathrm{B}_{\ldots}$ & $\mathbf{M}_{\mathrm{cos}}$ & $\mathbf{M}_{s o t}$ & $\mathrm{~m}_{\mathrm{cus}}$ & $\mathrm{m}_{\mathrm{w}}$ \\
\hline Dimension & MW & $\mathrm{t} / \mathrm{h}$ & $\mathrm{t} / \mathrm{h}$ & $\mathrm{t} / \mathrm{h}$ & $\mathrm{t} / \mathrm{h}$ & $\mathrm{t} / \mathrm{MW}$ & $\mathrm{t} / \mathrm{MW}$ \\
\hline \multirow{5}{*}{ Burning only lignite coal } & 145.74 & 216.72 & 0.00 & 163.27 & 8.56 & \multirow{5}{*}{1.1203} & \multirow{5}{*}{0.0587} \\
\hline & 168.53 & 252.72 & 0.00 & 188.81 & 9.89 & & \\
\hline & 190.79 & 288.72 & 0.00 & 213.74 & 11.20 & & \\
\hline & 212.53 & 324.78 & 0.00 & 238.10 & 12.48 & & \\
\hline & 225.28 & 346.32 & 0.00 & 252.38 & 13.23 & & \\
\hline \multirow{5}{*}{$\begin{array}{c}\text { Coal + Gas Turbine }=37.5 \mathrm{MW} \\
\text { (without HPH } 7 \text { and HPH 6) }\end{array}$} & 180.70 & 180.72 & 7.20 & 180.23 & 8.41 & 0.99739 & 0.04653 \\
\hline & 204.38 & 216.72 & 7.20 & 206.75 & 9.80 & 1.01163 & 0.04794 \\
\hline & 227.41 & 252.72 & 7.20 & 232.55 & 11.15 & 1.02263 & 0.04903 \\
\hline & 249.85 & 288.72 & 7.20 & 257.70 & 12.47 & 1.03141 & 0.04990 \\
\hline & 262.76 & 310.32 & 7.20 & 272.16 & 13.22 & 1.03578 & 0.05033 \\
\hline
\end{tabular}

As mentioned above, the reduction in sulfur dioxide $\mathrm{SO}_{2}$ emissions is mainly due to the lack of sulfur content in the gas fuel burned by the gas turbine. Fig. 6 shows how the specific consumption of sulfur dioxide changes as a function of the electricity produced by the unit. At maximum load, this decrease is by $14.30 \%$ and at minimum load goes up to $20.81 \%$. This is again due to the fact that the reduction of the load of the unit is carried out at the expense of reducing the combustion of lignite coal, which contains the sulfur that when burned generates sulfur dioxide in the flue gases. 


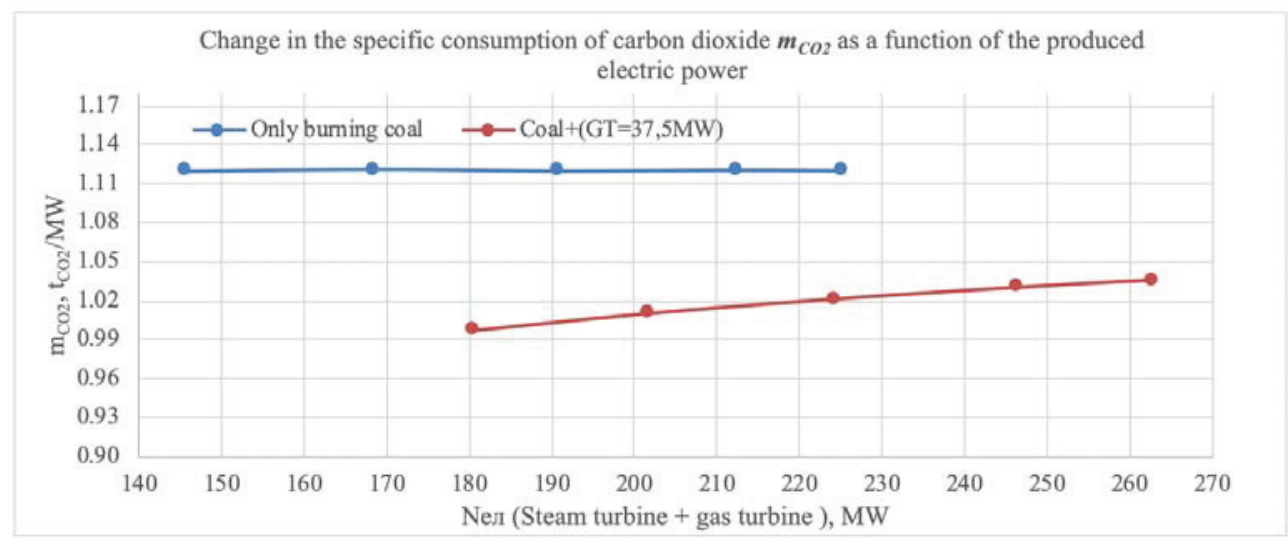

Fig. 5. Change in the specific consumption of carbon dioxide as a function of the produced electric power

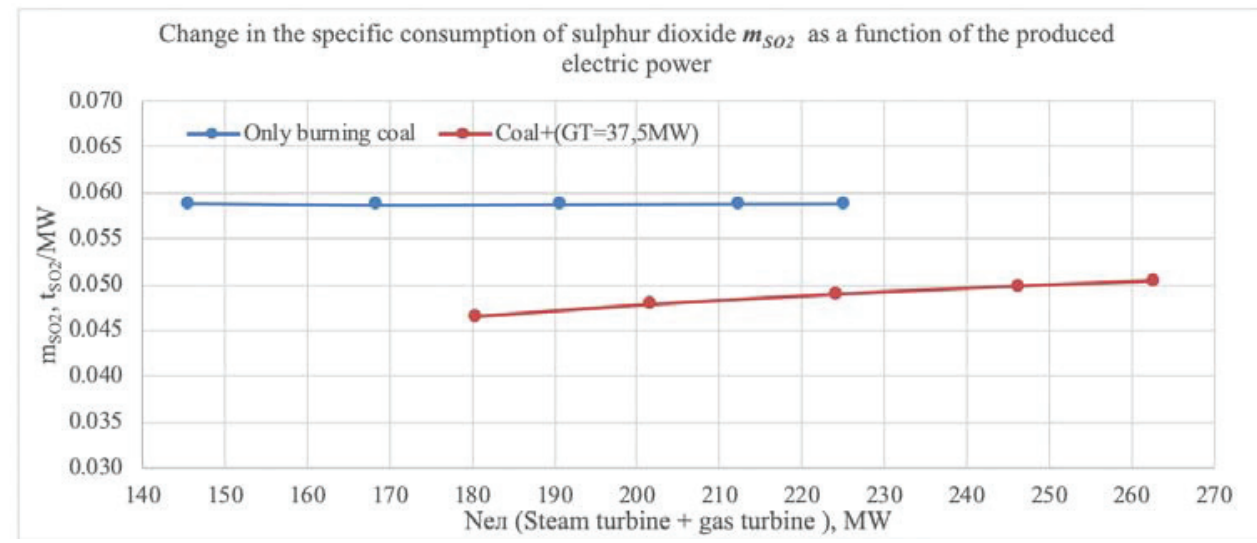

Fig. 6. Change in the specific consumption of sulphur dioxide as a function of the produced electric power

\section{Conclusions}

Combining a lignite power unit from the Maritsa East Complex with a gas turbine with a capacity of $37.5 \mathrm{MW}$ has the following advantages:

1. The proposed scheme in which a gas turbine and a lignite power unit work in combination requires minimal changes. The presence of a gas turbine does not impair the operability of the existing unit and it retains the ability to operate independently;

2. It increases the capacity of the power unit by $37.5 \mathrm{MW}$ which now reaches up to 262.7 MW, while maintaining the operating range of the conventional unit (from 145 to $225 \mathrm{MW}$ );

3. The efficiency of the combined cycle of a lignite power unit and a gas turbine (from $37.5 \mathrm{MW}$ ) increases on average by $3.5 \%$;

4. The consumption of lignite coal is reduced by about $36.0 \mathrm{t} / \mathrm{h}$ at maximum load, which will lead to a reduction of the unit's own needs for fuel preparation;

5. The carbon dioxide emissions of the power unit are reduced by $7.45 \%$ at maximum load to $10.98 \%$ at minimum load. This will reduce the unit's cost of purchasing carbon allowances; 
6. The generation of sulfur dioxide $\mathrm{SO}_{2}$ emissions is reduced by $14.30 \%$ at maximum load to $20.81 \%$ at minimum load. This will lead to additional savings from: limestone delivery; reduction of the unit's own needs for limestone preparation and its subsequent use in the flue-gas desulfurization FGD systems;

7. Reducing the consumption of lignite coal will lead to a reduction in emissions of other pollutants, such as: dust; mercury, fluorides; chlorides; and others.

8. Reducing the own needs of the power unit as a whole. Quantitative assessment of this effect will be shown in future studies

\section{References}

1. Chr. Petkov, T. Totev, H Thirerbach, FPEPM 2013, 1, 8-13;

2. Al. Grigorov, , International Journal of Siences: Basic and Applied Research (IJSBAR) 27, 1, (2016);

3. M. Q. Jabbar, B. Bonev, Al. Grigorov, Thermal Engineering, 7, 49-52;

4. K. Hristov, Iv. Genovski, FPEPM 2013 1, 137-143;

5. M. S. del Rio, J. Gibbins, M Lucquiaud, 58, 299-311, (2017);

6. S. O. Bashadi, H. J. Herzog, Energy Procedia 4, 1828-1834, (2011) ;

7. M Lucquiaud, J. Gibbins, Energy Procedia 4, 1812-1819, (2011);

8. N. Razi, H. F. Svendsen, O. Bolland, International Journal of Greenhouse Gas Control, 19, 478-491, (2013);

9. M Lucquiaud, J. Gibbins, International Journal of Greenhouse Gas Control, 5, 427438, (2011);

10. Lucquiaud, Steam cycle options for capture-ready power plants, retrofits and flexible operation with post-combustion CO2 capture, Imperial College London, PhD, (2010); 